\title{
Kahramanmaraş Organize Sanayi Bölgesi Atık Sularının Sır Baraj Gölü'nde Meydana Getirdiği Ağır Metal Kirliliğinin Belirlenmesi
}

\author{
Özgür CANPOLAT ${ }^{1 *}$, Seval UZUN ${ }^{2}$ \\ ${ }^{1}$ Fırat Üniversitesi, Su Ürünleri Fakültesi, Elazı̆̆ \\ ${ }^{2}$ Tarım ve Orman Il Müdürlüğü, Balıkçılık ve Su Ürünleri Şube Müdürlüğü, Hatay \\ (ORCID: 0000-0001-7498-600X) (ORCID: 0000-0002-9657-0598
}

\begin{abstract}
Öz
Bu çalışmada, Kahramanmaraş organize sanayi bölgesinde çeşitli sektörlerde üretim yapan fabrikaların deşarj ettikleri atık sularda ve bu atık suların karıştığı Sır Baraj Gölü ve Aksu Çayı (Kahramanmaraş)'nda suda ağır metal düzeylerinin tespit edilmesi ve bu değerlerin çeşitli kuruluşlar (WHO, USEPA ve EC) tarafindan önerilen standart değerlerle karşılaştırılması amaçlanmıştır. Bu amaç doğrultusunda hem atık sularda hem de Sır Baraj Gölü ve Aksu Çayı'nda suda bazı ağır metallerin (demir, bakır, çinko, krom, kadmiyum, nikel, arsenik ve civa) konsantrasyonlarının mevsimsel değişimi belirlenmiştir. Suda analizi gerçekleştirilen ağır metallerden $\mathrm{Fe}, \mathrm{Cu}$ ve $\mathrm{Zn}$ her mevsimde tüm istasyonlarda tespit edilirken, $\mathrm{Cr}$, $\mathrm{Ni}$ ve $\mathrm{Cd}$ sadece atık sularda tespit edilmiştir. As ve $\mathrm{Hg}$ değerleri ise cihazın ölçüm duyarlılığının altında kaldığından tespit edilememiştir. Aksu Çayı ve Sır Baraj Gölü’nde belirlenen istasyonlardan alınan su örneklerindeki ağır metal değerleri, WHO, USEPA ve EC tarafindan verilen standart değerlere göre karşılaştırılmıştır. Buna göre $\mathrm{Fe}, \mathrm{Cu}, \mathrm{Zn}, \mathrm{Cr}$ ve Ni konsantrasyonları WHO, USEPA ve EC tarafından belirlenen maksimum değerlerin çok üzerinde çıkmıştır. Bu veriler 1şığında tekstil, kaplama ve diğer endüstri fabrikalarından Aksu Çayı'na deşarj olan atık suların Sır Baraj Gölü’ne ağır metal taşıdığı ortaya çıkmaktadır.
\end{abstract}

Anahtar kelimeler: Ağır metal, çevre kirliliği, atık su, Sır Barajı Gölü, Aksu Çayı

\section{The Determination of Heavy Metal Pollution of Wastewaters of Kahramanmaras Organized Industrial Zone in Sir Dam Lake}

\begin{abstract}
In this study, it was aimed to determine some heavy metal levels in wastewater discharged from various sectors within the province of Kahramanmaras Organized Industrial Zone and water in Sir Dam Lake and Aksu Stream, and compare the results to the standard values set by the various organization (WHO, USEPA and EC). In line with these purposes, the seasonal variation of some heavy metals (iron, copper, zinc, chromium, cadmium, nickel, arsenic and mercury) in water has been determined in wastewaters both in Sir Dam Lake and Aksu Stream. While among heavy metals unit; $\mathrm{Fe}, \mathrm{Cu}$ and $\mathrm{Zn}$ were detected in all stations and in all seasons, $\mathrm{Cr}, \mathrm{Ni}$ and $\mathrm{Cd}$ were determined only at wastewaters. The As and $\mathrm{Hg}$ were not detected in any station since the levels were under the sensitivity of the measurement device. The heavy metal values taken from the samples stations set in the Aksu River and Sir Dam Lake were also compared to the standard values set by the WHO, USEPA and EC. Accordingly, $\mathrm{Fe}, \mathrm{Cu}, \mathrm{Zn}, \mathrm{Cr}$ and $\mathrm{Ni}$ concentrations were higher than the maximum values determined by the WHO, USEPA and EC. In the light of these data, it is clear that the waste water which is discharged from textile, coating and other industrial factories to Aksu Stream carries heavy metal to the Sir Dam Lake.
\end{abstract}

Keywords: Heavy metal, environmental pollution, wastewater, Sir Dam Lake, Aksu Stream.

\section{Giriş}

Günümüz dünyasının en önemli sorunlarından birini çevre sorunları oluşturmaktadır. Bugüne kadar sınırsız bir kaynak olarak kabul edilen doğa; hızlı sanayileşme ve nüfus artışı ile birlikte olumsuz yönde

*Sorumlu yazar:ocanpolat@firat.edu.tr

Geliş Tarihi: 05.03.2019, Kabul Tarihi: 11.07.2019 
etkilenmiştir. Çevrenin hızla tahrip edilmesi suretiyle kaynaklar tüketilmeye başlanmış ve bunun sonucu olarak da çevre kirliliği kaçınılmaz olmuş ve yaşam döngüsünü tehdit eden bir noktaya ulaşmıştır.

Birleşmiş Milletler Çevre Programı (UNEP) tarafından "Kara Liste"de yer alan maddeler arasında ağır metaller son derece önemli yer tutmaktadır. Günümüzde oldukça yaygın olan metal kirliliğine sebep olan beş kaynak vardır. Bunlar; jeolojik olaylar, maden filizleri ve metallerin endüstriyel üretimi, metal ve metal bileşiklerinin kullanımı, çöp ve katı atıkların doğaya boşaltılması, ağır metal içeren hayvan ve insan atıklarıdır [1-6]. Kentleşme, sanayi, metalurji ve endüstri alanında son zamanlarda gerçekleşen hızlı ilerlemelerle doğru orantılı olarak alüminyum, civa, bakır, kobalt, çinko, demir, nikel, kurşun ve kadmiyum gibi ağır metallerin boya sanayi, plastik sanayi, kağıt, kaplamacılık, pil ve zirai ilaç yapımında kullanılmaları neticesinde, bu metallerin sucul ekosistemlere karışma oranlarında artma olduğu belirlenmiştir [7].

Ağır metaller, genellikle iz element veya mikrobesin maddeleri olarak da ifade edilmektedir [8]. Doğal olarak bulunan 90 elementten 53 tanesi ağır metal grubunda yer almaktadır. Bu gruba kurşun, kadmiyum, krom, demir, kobalt, bakır, nikel, civa ve çinko gibi elementler dahildir. Ancak bunlardan sadece 17 tanesi biyolojik olarak mevcut olup ekosistem için de önem teşkil etmektedir. $\mathrm{Mo}, \mathrm{Cu}, \mathrm{Zn}$, $\mathrm{Cr}$, Ni, Fe ve Co enzim ve pigmentlerin yap1 taş1 olarak canlılar için önemli olan temel mikro elementlerdendir. Bunun yanı sira bütün metaller ve metaloidler yüksek konsantrasyonlarda bulunduklarında canlılar üzerinde toksik etki gösterebilmektedir $[9,10]$.

Sürekli alıcı ortam özelliği gösteren baraj gölleri çevre kirliliğinden birinci derecede etkilenirler. $\mathrm{Bu}$ kirlenme içinde yaşayan canlıları olumsuz etkilemesinin yanı sıra besin zinciri yoluyla insana kadar ulaşmaktadır [11].

Kahramanmaraş ilinde mevcut olan geleneksel el sanatları yerini hızlı bir şekilde tekstil ağırlıklı fabrikalara bırakmış olup, tekstil endüstrisi kollarında faaliyet gösteren 201 adet tesis ve 11 adet deri işleme atölyesi bulunmaktadır. Bunun yanı sıra bir adet mezbahane, 50'si metal eşya endüstrisi alanlarında, 15'i gıda, 5'i kimya ve 3'ü kağıt sanayi alanlarında olmak üzere çok sayıda endüstriyel tesis faaliyet göstermektedir [12, 13]. Bu endüstri alanları şehrin özel konumu nedeniyle daha çok akarsuların da içerisinde bulunduğu ovada yoğunlaşmış olup, şehir çevresindeki verimli ovada ilaçlı ve gübreli zirai faaliyetler sürdürülmektedir. Bütün bu gelişmeler şehir yakınında yer alan akarsularda aşırı kirlenme yönünde baskı yapmaktadır. Şehir ve çevresinde su kullanımına olan ihtiyaç artmış ve buna paralel olarak pahalı su temini projelerine ihtiyaç duyulmaya başlanmıştır [13].

$\mathrm{Bu}$ çalışmada Kahramanmaraş organize sanayi bölgesinde çeşitli sektörlerde üretim yapan fabrikaların deşarj ettikleri atık sularda ve bu atık suların karıştığı Sır Baraj Gölü ve Aksu Çayı (Kahramanmaraş)'nda sudaki bazı ağır metallerin düzeylerinin belirlenmesi ve bu değerlerin çeşitli kuruluşlar (WHO, USEPA ve EC) tarafından önerilen standart değerlerle karşılaştırılarak ağır metal kirlilik durumunun belirlenmesi amaçlanmıştır.

\section{Materyal ve Metot}

\section{1. Çalışma Bölgesi}

Sır Barajı, Kahramanmaraş ilinin 35 km güneybatısında Ceyhan Nehri üzerinde enerji üretmek amacıyla kurulmuştur. Baraj gölü kısmı Kahramanmaraş-Kayseri karayolunda bulunan Ceyhan Nehri köprüsüne, Aksu Çayı ve Deliçay Deresi'nin birleştiği yere kadar çıkmakta olup, Kahramanmaraş'a yaklaşık 8-10 km'lik bir mesafede bulunmaktadır. Sır Baraj Gölü elektrik üretmek amacıyla 1991 yılında inşaat çalışmaları tamamlanmış ve işletmeye alınmıştır [14]. Sır Baraj Gölü son yıllarda özellikle gerek evsel ve gerekse de endüstriyel atıklar dolayısıyla kirlenme baskısı altındadır $[15,16]$.

Engizek Dağı'nın eteklerinden doğan Aksu Çayı Ceyhan Nehri'nin en güçlü kollarından biridir. Küçükcerit Köyü'nün hemen doğusundan çok güçlü bir pınardan çıkan Aksu Çayı, Büyükcerit yönünden gelen sularla da beslenerek oldukça güçlü bir Çay durumuna gelir. Aksu Vadisi, Pazarcık yakınlarında genişleyerek Narlı Ovası'na açılır. Aksu Çayı, bu ovada önce güneybatı yönünde akar, sonra kuzeybatı, daha sonra da kuzeye yönelerek daha ileride yan derelerden gelen suları da toplayarak Kahramanmaraş'ın güney batısında Sır Barajı'na dökülür [15].

Araştırma, Temmuz 2012 tarihinde başlayıp, Nisan 2013 tarihinde tamamlanmıştır. Örneklemeler mevsimsel olarak yapılmıştır. Bu çalışma, 37³0'34.40" kuzey enlemleri ve 3654'31.89" doğu boylamlarında yer alan bölgede (Şekil 1); 
- Kahramanmaraş Organize Sanayi Bölgesi atık sularının Aksu Çayı'na deşarj olduğu kanal (1.

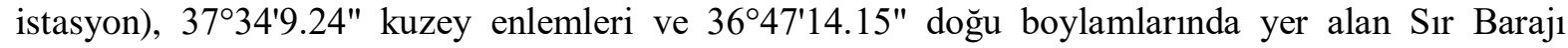
mevkiinde (Şekil 1),

- Kahramanmaraş Organize Sanayi Bölgesi atık sularının Aksu Çayı'na karıştığı bölge (2. istasyon), (Şekil 2),

- Kahramanmaraş Organize Sanayi Bölgesi atık sularının Sır Baraj Gölü’ne karıştı̆ğ bölge (3. istasyon), (Şekil 2),

- Kahramanmaraş Organize Sanayi Bölgesi atık sularının Sır Baraj Gölü’ne karıştı̆ı̆ bölgeden uzak açık bölge (4. ve 5. istasyon), (Şekil 2),

- Herhangi bir endüstriyel kuruluşun atık sularının Sır Baraj Gölü’ne karışmadığı bölgede (6.İstasyon), (Şekil 2) yürütülmüştür.

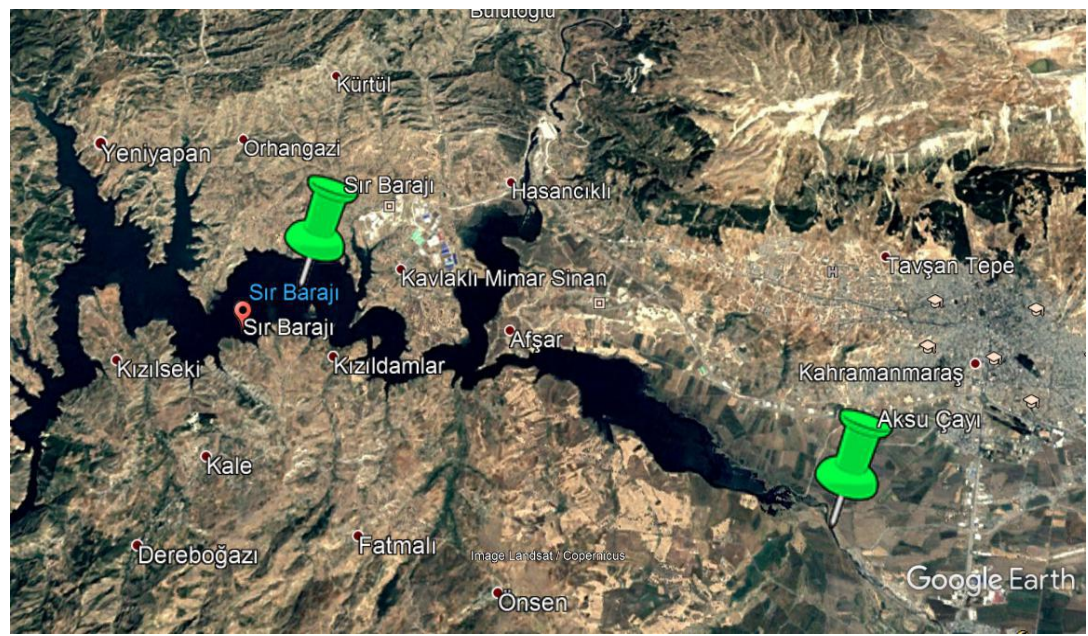

Şekil 1. Sır Baraj Gölü’nün ve Aksu Çayı'nın coğrafik konumu [17]

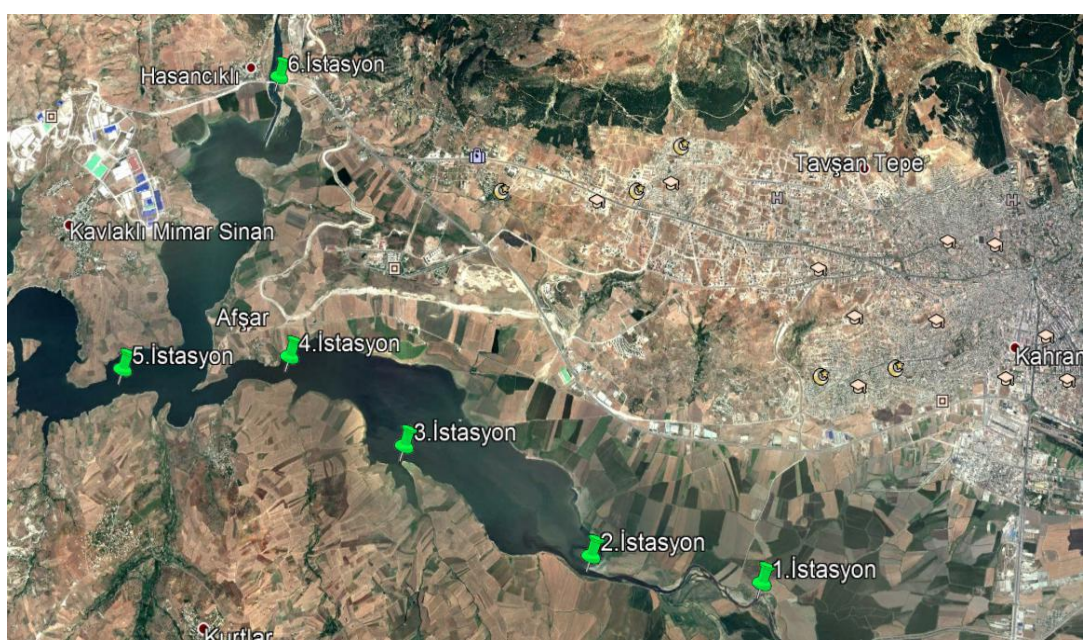

Şekil 2. Örnekleme yapılan istasyonlar [17]

\subsection{Su Örneklerinde Yapılan Ağır Metal Analizleri}

Sudaki ağır metal analizleri için numune alımında kullanılan kapların temiz ve kirlenmeye yol açmayacak şekilde olmasına dikkat edilmiştir. Örnekler 1., 2. ve 3. İstasyonlarda numune kapları atık suya daldırılarak, 4., 5. ve 6. İstasyonlarda ise Nansen Şişesi kullanılarak yüzeyden $1 \mathrm{~m}$ derinlikten alınmıştır. Alınan su örnekleri, kimyasallar için uygun, akmaya ve sızıntıya karşı dayanıklı olan 1 L'lik steril polietilen şişelere bırakılmıştır. Alınan su örneklerindeki organizmaların ağır metalleri parçalayarak kimyasal reaksiyon başlatmaların engellemek amacıyla suya $\% 1$ oranında nitrik asit $\left(\mathrm{HNO}_{3}\right)$ ilave edilerek pH'1 2'ye düşürülmüştür. Nitrik asit çözeltisi, ultra saf \%65'lik nitrik asitten saf 
su ile günlük olarak hazırlanmıştır [18]. Sudaki ağır metal analizi için, $50 \mathrm{ml}$ su numunesi alınarak Kjeldahl balonlarına konulmuş, içine nitrik asit ve sülfürik asit (5/10) karışımından $5 \mathrm{ml}$ ilave edilerek mineralizasyon işlemine tabi tutulmuş ve 25 ml'ye deriştirilmiştir [19]. Su örneklerinde bakır (Cu), demir (Fe), çinko $(\mathrm{Zn})$, krom $(\mathrm{Cr})$, nikel (Ni), kadmiyum (Cd), arsenik (As) ve civa (Hg) konsantrasyonları, hizmet alımı şeklinde özel bir laboratuvarda İndüktif Eşleşmiş Plazma (ICP) cihazında belirlenmiştir. Analize hazır duruma getirilen su örnekleri numune kaplarına konularak ağır metal analizlerinin gerçekleştirileceği laboratuvara soğuk muhafazalı olarak gönderilmiştir.

ICP cihazında analizi gerçekleştirilen elementlerin dalga boyları aşağıda verilmiştir;

$\mathrm{Cu}=237,393 \mathrm{~nm}$

$\mathrm{Fe}=238,204 \mathrm{~nm}$

$\mathrm{Zn}=206,200 \mathrm{~nm}$

$\mathrm{Cr}=267,716 \mathrm{~nm}$

$\mathrm{Ni}=231,604 \mathrm{~nm}$

$\mathrm{Cd}=228,802 \mathrm{~nm}$

As $=188,979 \mathrm{~nm}$

$\mathrm{Hg}=253,652 \mathrm{~nm}$

\section{Bulgular ve Tartışma}

Suda analizi gerçekleştirilen ağır metallerden $\mathrm{Fe}, \mathrm{Cu}$ ve $\mathrm{Zn}$ her mevsimde tüm istasyonlarda tespit edilmiştir. $\mathrm{Cr}$, $\mathrm{Ni}$ ve $\mathrm{Cd}$ sadece atık sularda belirlenirken, diğer istasyonlarda cihazın ölçüm duyarlığının altında $(\mathrm{Cr}<0,9 \mathrm{mg} / \mathrm{L}, \mathrm{Ni}<0,3 \mathrm{mg} / \mathrm{L}, \mathrm{Cd}<1,4 \mathrm{mg} / \mathrm{L})$ kaldığından belirlenememiştir. As $(<1,7 \mu \mathrm{g} / \mathrm{L})$ ve $\mathrm{Hg}(<0,08 \mu \mathrm{g} / \mathrm{L})$ ise bütün istasyonlarda cihazın ölçüm duyarlığının altında kaldığından tespit edilememiştir.

Demir (Fe): En yüksek Fe konsantrasyonu Kahramanmaraş Organize Sanayi Bölgesi atık sularının Sır Baraj Gölü’ne karıştığı bölgede bulunan 3. istasyonda sonbahar mevsiminde (84,4 mg/L), en düşük Fe konsantrasyonu ise herhangi bir endüstriyel kuruluşun atık sularının Sır Baraj Gölü'ne karışmadığı alan olarak belirlenen bölgede bulunan 6 . İstasyonda ilkbahar mevsiminde $(9,1 \mathrm{mg} / \mathrm{L})$ tespit edilmiştir (Tablo 1).

Tablo 1. Örnekleme yapılan istasyonlarda Fe konsantrasyonunun mevsimsel değişimi (mg/L)

\begin{tabular}{|l|c|c|c|c|}
\hline & Yaz (2012) & Sonbahar (2012) & Kış (2013) & İlkbahar (2013) \\
\hline 1. İstasyon & 77,2 & 57,8 & 62,2 & 60,7 \\
\hline 2. İstasyon & 72,9 & 62,8 & 60,9 & 59,8 \\
\hline 3. İstasyon & 71,2 & 84,4 & 72,4 & 60,1 \\
\hline 4. İstasyon & 13,7 & 11,5 & 12,2 & 10,9 \\
\hline 5. İstasyon & 12,4 & 13 & 13,7 & 9,6 \\
\hline 6. İstasyon & 10,1 & 11,8 & 12,2 & 9,1 \\
\hline
\end{tabular}

Çinko (Zn): Zn konsantrasyonunun mevsimsel değişimi dikkate alındığında en yüksek Zn değerleri Kahramanmaraş Organize Sanayi Bölgesi atık sularının karıştığı Aksu Çayı bölgesinde bulunan 2. İstasyonda yaz mevsiminde $(61,3 \mathrm{mg} / \mathrm{L})$ belirlenirken, en düşük $\mathrm{Zn}$ konsantrasyonu ise 6 . İstasyonda ilkbahar mevsiminde $(5,8 \mathrm{mg} / \mathrm{L})$ saptanmıştır (Tablo 2$)$.

Tablo 2. Örnekleme yapılan istasyonlarda Zn konsantrasyonunun mevsimsel değişimi (mg/L)

\begin{tabular}{|l|c|c|c|c|}
\hline & Yaz (2012) & Sonbahar (2012) & Kış (2013) & İlkbahar (2013) \\
\hline 1. İstasyon & 57,1 & 56,4 & 48,5 & 33,5 \\
\hline 2. İstasyon & 61,3 & 58,5 & 43,6 & 32,7 \\
\hline 3. İstasyon & 60,4 & 44,4 & 45,3 & 40,3 \\
\hline 4. İstasyon & 10,2 & 10,9 & 11,2 & 6,3 \\
\hline 5. İstasyon & 12,7 & 12,4 & 8,9 & 7,4 \\
\hline 6. İstasyon & 15,6 & 9,2 & 7,8 & 5,8 \\
\hline
\end{tabular}


Bakır (Cu): $\mathrm{Cu}$ konsantrasyonunun istasyonlara göre mevsimsel değişimi göz önüne alındığında en yüksek Cu konsantrasyonu 1. İstasyonda yaz mevsiminde $(20,0 \mathrm{mg} / \mathrm{L})$ tespit edilmiştir. En düşük $\mathrm{Cu}$ konsantrasyonu ise $\mathrm{Fe}$ ve $\mathrm{Zn}$ elementlerinde olduğu gibi 6. İstasyonda ilkbahar mevsiminde $(0,10 \mathrm{mg} / \mathrm{L})$ belirlenmiştir (Tablo 3$)$.

Tablo 3. Örnekleme yapılan istasyonlarda $\mathrm{Cu}$ konsantrasyonunun mevsimsel değişimi (mg/L)

\begin{tabular}{|l|c|c|c|c|}
\hline & Yaz (2012) & Sonbahar (2012) & Kış (2013) & İlkbahar (2013) \\
\hline 1. İstasyon & 20 & 19,7 & 18,1 & 16 \\
\hline 2. İstasyon & 15 & 14,4 & 13,2 & 15,3 \\
\hline 3. İstasyon & 18 & 14,2 & 17,4 & 15 \\
\hline 4. İstasyon & 0,14 & 0,18 & 0,17 & 0,18 \\
\hline 5. İstasyon & 0,16 & 0,13 & 0,12 & 0,11 \\
\hline 6. İstasyon & 0,12 & 0,19 & 0,13 & 0,10 \\
\hline
\end{tabular}

Krom (Cr): En yüksek Cr konsantrasyonu 2. İstasyonda sonbahar mevsiminde (29,9 mg/L),

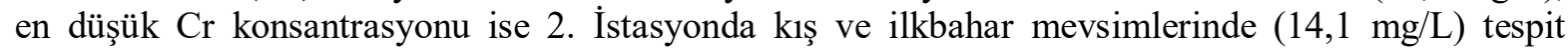
edilmiştir (Tablo 4).

Tablo 4. Örnekleme yapılan istasyonlarda Cr konsantrasyonunun mevsimsel değişimi (mg/L)

\begin{tabular}{|l|c|c|c|c|}
\hline & Yaz (2012) & Sonbahar (2012) & Kış (2013) & İlkbahar (2013) \\
\hline 1. İstasyon & 18,8 & 19,2 & 16,5 & 16,5 \\
\hline 2. İstasyon & 17,6 & 29,9 & 14,1 & 14,1 \\
\hline 3. İstasyon & 19,2 & 25,7 & 16,9 & 16,9 \\
\hline
\end{tabular}

Nikel (Ni): Ni konsantrasyonunun istasyonlara göre mevsimsel değişimi dikkate alındığında en yüksek Ni konsantrasyonu $(1,9 \mathrm{mg} / \mathrm{L}) \quad 1$. İstasyonda sonbahar mevsiminde ve 3. İstasyonda yaz mevsiminde belirlenmiştir. En düşük Ni konsantrasyonu $(1,1 \mathrm{mg} / \mathrm{L})$ ise 1 . İstasyonda ilkbahar mevsiminde ve 2. İstasyonda kış mevsiminde belirlenmiştir (Tablo 5).

Tablo 5. Örnekleme yapılan istasyonlarda Ni konsantrasyonunun mevsimsel değişimi (mg/L)

\begin{tabular}{|l|c|c|c|c|}
\hline & Yaz (2012) & Sonbahar (2012) & Kış (2013) & İlkbahar (2013) \\
\hline 1. İstasyon & 1,8 & 1,9 & 1,3 & 1,1 \\
\hline 2. İstasyon & 1,6 & 1,6 & 1,1 & 1,5 \\
\hline 3. İstasyon & 1,9 & 1,2 & 1,7 & 1,3 \\
\hline
\end{tabular}

Kadmiyum (Cd): Araştırma süresince en yüksek Cd konsantrasyonu 3. İstasyonda yaz mevsiminde $(8,6 \mu \mathrm{g} / \mathrm{L})$, en düşük Cd konsantrasyonu ise yine 3. İstasyonda kış mevsiminde $(5,2 \mu \mathrm{g} / \mathrm{L})$ kaydedilmiştir (Tablo 6).

Tablo 6. Örnekleme yapılan istasyonlarda Cd konsantrasyonunun mevsimsel değişimi $(\mu \mathrm{g} / \mathrm{L})$

\begin{tabular}{|l|c|c|c|c|}
\hline & Yaz (2012) & Sonbahar (2012) & Kış (2013) & İlkbahar (2013) \\
\hline 1. İstasyon & 8,2 & 7,5 & 7 & 6,5 \\
\hline 2. İstasyon & 7,9 & 6,8 & 6,3 & 5,7 \\
\hline 3. İstasyon & 8,6 & 7,4 & 5,2 & 5,6 \\
\hline
\end{tabular}

Bu çalışmada, Kahramanmaraş Organize Sanayi Bölgesi atık sularının karıştığı Sır Baraj Gölü ve Aksu Çayı'ndan alınan su örneklerinde demir ( $\mathrm{Fe})$, çinko $(\mathrm{Zn})$, bakır $(\mathrm{Cu})$, krom $(\mathrm{Cr})$, nikel (Ni) ve kadmiyum $(\mathrm{Cd})$ konsantrasyonlarının mevsimlere göre değişimleri belirlenmiştir. Kahramanmaraş Organize Sanayi Bölgesi atık sularının Aksu Çayı'na deşarj olduğu kanalda belirlenen 1. İstasyonda tespit edilen ağır metal değerlerinin; $\mathrm{Fe}=57,8-77,2 \mathrm{mg} / \mathrm{L}, \mathrm{Cu}=16,0-20,0 \mathrm{mg} / \mathrm{L}, \mathrm{Zn}=33,5-57,1 \mathrm{mg} / \mathrm{L}$, $\mathrm{Cr}=16,5-19,2 \mathrm{mg} / \mathrm{L}, \mathrm{Ni}=1,1-1,9 \mathrm{mg} / \mathrm{L}$ ve $\mathrm{Cd}=6,5-8,2 \mu \mathrm{g} / \mathrm{L}$ arasında değişim gösterdiği belirlenmiştir. 
Aksu Çayı'nda belirlenen 2. İstasyondan alınan su örneklerindeki ağır metal konsantrasyonlarının $\mathrm{Fe}=59,8-72,9 \mathrm{mg} / \mathrm{L}, \mathrm{Cu}=13,2-15,3 \mathrm{mg} / \mathrm{L}, \mathrm{Zn}=32,7-61,3 \mathrm{mg} / \mathrm{L}, \mathrm{Cr}=14,1-29,9$ $\mathrm{mg} / \mathrm{L}, \quad \mathrm{Ni}=1,1-1,6 \quad \mathrm{mg} / \mathrm{L}$ ve $\mathrm{Cd}=5,7-7,9 \mu \mathrm{g} / \mathrm{L}$ arasında değişim gösterdiği tespit edilmiştir. Kahramanmaraş Organize Sanayi Bölgesi atık sularının Sır Baraj Gölü'ne karıştığı bölgede belirlenen 3. İstasyondan alınan su örneklerindeki ağır metal konsantrasyonları göz önüne alındığında $\mathrm{Fe}=60,1-$ $84,4 \mathrm{mg} / \mathrm{L}, \mathrm{Cu}=14,2-18,0 \mathrm{mg} / \mathrm{L}, \mathrm{Zn}=40,3-60,4 \mathrm{mg} / \mathrm{L}, \mathrm{Cr}=16,9-25,7 \mathrm{mg} / \mathrm{L}, \mathrm{Ni}=1,2-1,9 \mathrm{mg} / \mathrm{L}$ ve $\mathrm{Cd}=5,2-8,6 \mu \mathrm{g} / \mathrm{L}$ arasında değişim gösterdiği bulunmuştur. Kahramanmaraş Organize Sanayi Bölgesi atık sularının Sır Baraj Gölü'ne karıştığı bölgeden uzak açık bölgede belirlenen 4. istasyondan alınan su örneklerindeki ağır metal konsantrasyonlarının $\mathrm{Fe}=10,9-13,7 \mathrm{mg} / \mathrm{L}, \mathrm{Cu}=0,14-0,18 \mathrm{mg} / \mathrm{L}$ ve $\mathrm{Zn}=6,3-$ $11,2 \mathrm{mg} / \mathrm{L}$ arasında değişim gösterdiği saptanmıştır. Kahramanmaraş Organize Sanayi Bölgesi atık sularının Sır Baraj Gölü’ne karıştı̆̆ 1 bölgeden uzak açık bölgede bulunan 5. istasyonda elde edilen ağır metal değerleri göz önüne alındığında, $\mathrm{Fe}=9,6-13,7 \mathrm{mg} / \mathrm{L}, \mathrm{Cu}=0,11-0,16 \mathrm{mg} / \mathrm{L}$ ve $\mathrm{Zn}=7,4-12,7 \mathrm{mg} / \mathrm{L}$ arasında değişim gösterdiği bulunmuştur. Çalışma alanı içerisinde belirlenen herhangi bir endüstriyel kuruluşun atık sularının Sır Baraj Gölü’ne karışmadığı bölge olan 6. istasyondan alınan su örneklerindeki ağır metal konsantrasyonlarının ise $\mathrm{Fe}=9,1-12,2 \mathrm{mg} / \mathrm{L}, \mathrm{Cu}=0,10-0,19 \mathrm{mg} / \mathrm{L}$ ve $\mathrm{Zn}=5,8$ $15,6 \mathrm{mg} / \mathrm{L}$ arasında değişim gösterdiği tespit edilmiştir. En düşük $\mathrm{Fe}, \mathrm{Cu}$ ve $\mathrm{Zn}$ konsantrasyonları bu istasyonda kaydedilmiştir. Su örneklerinde tespit edilen ağır metal konsantrasyonları dikkate alındığında istasyonlara göre değişiklik gösterdiği belirlenmiştir. Bütün istasyonlarda $\mathrm{Fe}, \mathrm{Cu}$ ve $\mathrm{Zn}$ tespit edilirken, $\mathrm{Ni}$ ve $\mathrm{Cd}$ sadece 1., 2. ve 3. istasyonlarda saptanmıştır.

Analizi gerçekleştirilen elementlerin mevsimsel değişimi dikkate alındığında en yüksek Fe konsantrasyonu 3. İstasyonda sonbahar mevsiminde, en düşük Fe konsantrasyonu ise 6 . İstasyonda ilkbahar mevsiminde tespit edilmiştir. En yüksek $\mathrm{Cu}$ konsantrasyonu 1. İstasyonda yaz mevsiminde belirlenmiş olup en düşük $\mathrm{Cu}$ konsantrasyonu 6. İstasyonda ilkbahar mevsiminde bulunmuştur. En yüksek Zn konsantrasyonu 2. İstasyonda yaz mevsiminde, en düşük Zn konsantrasyonu ise yine 6 . İstasyonda ilkbahar mevsiminde belirlenmiştir. Çalışma süresince $\mathrm{Cr}$ sadece 1., 2. ve 3. İstasyonlarda tespit edilmiş olup en yüksek $\mathrm{Cr}$ konsantrasyonu 2. İstasyonda sonbahar mevsiminde, en düşük $\mathrm{Cr}$ konsantrasyonu ise 2. İstasyonda kış ve ilkbahar mevsimlerinde tespit edilmiştir. Ni konsantrasyonunun mevsimsel değişimi dikkate alındığında $\mathrm{Cr}$ elementinde olduğu gibi sadece 1., 2. ve 3. İstasyonlarda belirlenmiş olup, en yüksek Ni konsantrasyonu 1. İstasyonda sonbahar mevsiminde ve 3. İstasyonda yaz mevsiminde, en düşük Ni konsantrasyonu ise 2. İstasyonda kış mevsiminde kaydedilmiştir. En yüksek $\mathrm{Cd}$ konsantrasyonu 3. İstasyonda yaz mevsiminde, en düşük Cd konsantrasyonu ise 3. İstasyonda kış mevsiminde tespit edilmiştir. Genel olarak bütün elementlerin en yüksek değerleri yaz mevsiminde, en düşük değerleri ise ilkbahar mevsiminde belirlenmiştir.

Teber [20], Sıdıklı Küçükboğaz Baraj Gölü'nden alınan su örneklerinde bazı ağır metallerin konsantrasyonlarını belirlemiştir. Sıdıklı Küçükboğaz Baraj Gölü’nden alınan su örneklerinde Cr'un bütün mevsimlerde analiz cihazının ölçüm duyarlılı̆̆ının altında olduğu, $\mathrm{Cu}$ elementinin ise sadece ağustos ayında tespit edildiği rapor edilmiştir. Teber [20], Fe ve $\mathrm{Zn}^{\prime}$ nun en yüksek değerlerini yaz mevsiminde kaydetmiştir. Bu çalışmada da en yüksek Fe konsantrasyonu sonbahar mevsiminde, en yüksek Zn konsantrasyonu ise yaz mevsiminde belirlenmiş olup, Teber [20]'in en yüksek Zn konsantrasyonu için elde etmiş olduğu veri ile benzerlik göstermiştir.

Sönmez vd. [21], Karasu Irmağı'nda belirledikleri beş istasyondan bir y1l süresince su örnekleri alarak $\mathrm{Fe}, \mathrm{Cu}, \mathrm{Zn}, \mathrm{Mn}, \mathrm{Ni}, \mathrm{Cd}$ ve $\mathrm{Pb}$ konsantrasyonlarını araştırmışlardır. Su örneklerindeki ağır metal konsantrasyonlarının; $\mathrm{Fe}=0,01-0,3 ; \mathrm{Cu}=0,05-0,79 ; \mathrm{Zn}=0,05-1,32 ; \mathrm{Mn}=0,02-0,99 ; \mathrm{Pb}=0,00-0.10$; $\mathrm{Ni}=0,01-0.14$ ve $\mathrm{Cd}=.000-0.008$ ppm arasında değişim gösterdiğini rapor etmişlerdir. Bu çalışmada elde edilen veriler göz önüne alındığında ağır metal konsantrasyonlarının Sönmez vd. [21]'nin Karasu Irmağı'nda suda buldukları değerlerden yüksek olduğu belirlenmiştir.

Kalyoncu vd. [22] Isparta Deresi'nde suda bazı ağır metallerin konsantrasyonlarını belirledikleri çalışmada, $\mathrm{Cu}$ ve $\mathrm{Zn}$ değerlerinin sadece bir istasyonda cihazın ölçüm duyarlılı̆̆ının altında kaldığı için belirlenemediğini, suda en fazla biriken ağır metalin $\mathrm{Fe}$, en az biriken ağır metalin ise $\mathrm{Cd}$ olduğunu bildirmişlerdir. Sudaki ağır metallerin konsantrasyonlarının $\mathrm{Cd}=0,06-1,37 ; \mathrm{Cr}=0,09-9,89 ; \mathrm{Cu}=0,77$ 35,$44 ; \mathrm{Ni}=10,41-55,50 ; \mathrm{Pb}=9,88-26,43 ; \mathrm{Zn}=1,09-57,90$ ve $\mathrm{Fe}=291,85-3082,41 \mathrm{ppb}$ arasında değişim gösterdiğini rapor etmiş̧lerdir. Kalyoncu vd. [22]'nin Isparta Deresi'nde belirledikleri ağır metal konsantrasyonları bu çalışmada elde edilen veriler ile karşılaştırıldığında Isparta Deresi'nde belirlenen ağır metal değerlerinin daha düşük olduğu tespit edilmiştir. 
Dündar vd. [23] çeşitli endüstri sanayilerinin atık sularında $\mathrm{Pb}, \mathrm{Cr}, \mathrm{Cu}, \mathrm{Zn}$ ve Ni düzeylerini belirledikleri çalışmada en yüksek $\mathrm{Cu}$ konsantrasyonunu $0,377 \mathrm{mg} / \mathrm{L}$ olarak kaplama ve tekstil sanayinde, en yüksek $\mathrm{Pb}$ konsantrasyonunu $0,103 \mathrm{mg} / \mathrm{L}$ olarak kaplama sanayinde, en yüksek $\mathrm{Ni}$ konsantrasyonunu $0,963 \mathrm{mg} / \mathrm{L}$ olarak kaplama sanayinde, en yüksek Zn konsantrasyonunu 0,106 mg/L olarak kaplama ve deri sanayinde, en yüksek Cr konsantrasyonunu ise $0,145 \mathrm{mg} / \mathrm{L}$ olarak kaplama ve deri sanayinde tespit etmişlerdir. Dündar vd. [23]'nin çeşitli endüstri kuruluşlarının atık sularında belirledikleri ağır metal konsantrasyonlarının bu çalışmada muhtelif sanayi atık sularının boşaldığı 1 . İstasyonda ölçülen değerlerden düşük olduğu belirlenmiştir. Araştırmanın yürütüldüğü sucul ekosistemlerde ağır metal konsantrasyonlarında görülen bu farklılık değişik sanayi türlerindeki atık suların farklı ağır metaller içerdiğini açıkça ortaya koymaktadır.

Toroğlu vd. [13] Aksu Çayı'nın kirliliğini araştırdıkları çalışmada Aksu Çayı'nda ve kollarında ağır metallerden kaynaklı yüksek oranlarda kirlenmenin olduğunu tespit etmişlerdir. Akarsuların $\mathrm{Pb}$, $\mathrm{Cu}, \mathrm{Fe}$ ve $\mathrm{Ni}$ bakımından kirli, $\mathrm{Mn}$ ve $\mathrm{Zn}$ bakımından az kirli veya temiz sular sinıfına girdiğini bildirmişlerdir. Toroğlu vd. [13] bakterilerin evsel, endüstriyel ve tarımsal kirlilik ortaya çıkaran maddelerin yapımında çok kullanıldığı düşünülen ve düşük konsantrasyonlarda bile toksik etki yapabilen ağır metallerle yapılan dirençlilik testlerinde endüstriyel kirlenmenin varlığını ortaya koymuşlardır. Ayrıca Aksu Çayı ve kollarında ağır metallerin meydana getirdiği kirliliğin yüksek seviyede olduğunu ve bu kirliliğin Sır Baraj Gölü'nde depolandığını rapor etmişlerdir. Toroğlu vd. [13]'nin elde ettiği bulgular, bu çalışmada elde edilen sonuçlara göre Aksu Çayı ve Sır Baraj Gölü’nde meydana gelen kirliliğin fazla olduğu bulgusunu desteklemektedir.

Uçkun vd [24] Atatürk Baraj Gölü (Fırat Nehri)'nden alınan su ve sediment örneklerinde bazı ağır metal konsantrasyonlarının ( $\mathrm{Fe}, \mathrm{Cu}, \mathrm{Pb}, \mathrm{As}, \mathrm{Hg}, \mathrm{Cr}, \mathrm{Mn}, \mathrm{Cd}, \mathrm{Co}, \mathrm{Zn}$ ve $\mathrm{Ni}$ ) mevsimsel değişimini araştırmışlardır. Uçkun vd [24] su örneklerindeki ortalama metal konsantrasyonlarını $\mathrm{Fe}=24,66$; $\mathrm{Zn}=4,38 ; \mathrm{Cu}=4,26 ; \mathrm{Mn}=2,95 ; \mathrm{Ni}=1,60 ; \mathrm{Pb}=1,078 ; \mathrm{Co}=0,745 ; \mathrm{As}=0,51 ; \mathrm{Cr}=0,311 ; \mathrm{Cd}=0,16$ ve $\mathrm{Hg}=0,015 \mathrm{mg} / \mathrm{L}$ olarak tespit etmişlerdir.

Minareci ve Çakır [25] Büyük Menderes Nehri üzerinde bulunan enerji üretimi, taşkın koruma ve tarımsal sulama amaçı inşa edilen Adıgüzel Baraj Gölü (Denizli)'nden aldıkları su örneklerinde bazı ağır metal düzeylerini tespit etmişlerdir. Minareci ve Çakır [25] su örneklerindeki ağır metal konsantrasyonlarının $\mathrm{Cu}=0,0004-0,0049 \mathrm{mg} / \mathrm{L}, \mathrm{Ni}=0,0043-0,0396 \mathrm{mg} / \mathrm{L}, \mathrm{Cr}=0,0009-0,0196 \mathrm{mg} / \mathrm{L}$ ve $\mathrm{Pb}=0-0,0004 \mathrm{mg} / \mathrm{L}$ arasında değişim gösterdiğini belirlemişlerdir. Gölde bor ve ağır metal konsantrasyonlarının kritik değerlerden düşük olmasının, gölün endüstri bölgesine ve termal suların çıktığı bölgeye uzak olmasından kaynaklandığı ve göl sularının özellikle tarımsal amaçlı sulama kullanımına uygun olduğu bildirilmiştir.

Uçkun vd [24]'nin Atatürk Baraj Gölü suyunda ve Minareci ve Çakır [25]'ın Adıgüzel Baraj Gölü suyunda buldukları ağır metal değerlerinin, bu araştırmada elde edilen değerlere göre daha düşük olduğu bulunmuştur.

Varol [26] Keban Baraj Gölü'nde suda bazı ağır metallerin (As, Cd, Co, Cr, Cu, Fe, Mn, Ni, Pb ve Zn) mevsimsel değişimini, bu ağır metallerin kaynaklarını tespit etmiş ve risk analizi yapmıştır. Varol [26] su örneklerindeki ağır metallerin mevsimsel değişimini $\mathrm{Fe}(\mu \mathrm{g} / \mathrm{L})$; sonbahar $=56$, kış=22, ilkbahar $=23, \quad$ yaz $=12 ; \mathrm{Cu}(\mu \mathrm{g} / \mathrm{L}) ;$ sonbahar $=6,1, \quad \mathrm{k}$ ş=4,8, ilkbahar $=4,1$, yaz $=1,8 ; \mathrm{Zn} \quad(\mu \mathrm{g} / \mathrm{L})$; sonbahar $=9,8, \mathrm{k} 1 s ̧=8,0$, ilkbahar $=5,6, \mathrm{yaz}=2,9 ; \mathrm{Cr}(\mu \mathrm{g} / \mathrm{L})$; sonbahar $=3, \mathrm{k} 1 s=2,9$, ilkbahar $=2,7, \mathrm{yaz}=2,5$; $\mathrm{Ni}(\mu \mathrm{g} / \mathrm{L})$; sonbahar $=3,6, \mathrm{k}$ ıs $=2,9$, ilkbahar $=2,3, \mathrm{yaz}=1,6 \mathrm{ve} \mathrm{Cd}(\mu \mathrm{g} / \mathrm{L})$; ilkbahar $=0,11$, yaz $=0,08$ olarak belirlemiştir. Varol [26] Keban Baraj Gölü'nde sudaki en yüksek ağır metal konsantrasyonlarını sonbahar mevsiminde, en düşük ağır metal konsantrasyonlarını ise yaz mevsiminde tespit etmiştir.

$\mathrm{Bu}$ araştırmada genel olarak bütün elementlerin en yüksek değerleri yaz mevsiminde, en düşük değerleri ise ilkbahar mevsiminde belirlenmiştir. Bu bulgu, Varol [26]'un elde ettiği bulgu ile farklılık göstermekte olup, bu farklılı̆̆ın Aksu Çayı ve Sır Baraj Gölü' ne karışan organize sanayi bölgesi atık su miktarının mevsimsel olarak değişiklik göstermesinden kaynaklanmış olabileceğini düşündürmektedir.

Araştırma süresince belirlenen istasyonlardan alınan su örneklerinde tespit edilen ağır metal konsantrasyonlarının USEPA [27] tarafından tatlı sular için oluşturulan kriterlere göre değerlendirilmesi Tablo 7'de verilmiştir. Bu çalışma sonucunda elde edilen ağır metal konsantrasyonları göz önüne alındığında $\mathrm{Fe}, \mathrm{Cu}, \mathrm{Zn}, \mathrm{Cr}$ ve Ni değerleri USEPA [27] standartlarının oldukça üstünde bulunmuştur. $\mathrm{Bu}$ verilere göre örnekleme yapılan bölgede ciddi bir ağır metal kirliliği olduğu ortaya çıkmaktadır. 
Tablo 7. Tatlı sular için önerilen ağır metal kriterleri (mg/L), [27]

\begin{tabular}{|l|c|c|c|c|c|}
\hline Metaller & $\mathbf{C u}$ & $\mathbf{F e}$ & $\mathbf{Z n}$ & $\mathbf{C r}$ & $\mathbf{N i}$ \\
\hline USEPA & 0,013 & - & 0,12 & 0,57 & 0,47 \\
\hline MK & 0,009 & 1 & 0,12 & 0,074 & 0,052 \\
\hline SK & & & & \\
\hline \multicolumn{5}{|l|}{ ISTASYONLAR } \\
\hline 1.Istasyon & 18,45 & 64,47 & 48,87 & 17,75 & 1,52 \\
\hline 2.İstasyon & 14,47 & 64,1 & 49,02 & 18,92 & 1,45 \\
\hline 3.İstasyon & 16,15 & 72,02 & 47,6 & 19,67 & 1,52 \\
\hline 4.İstasyon & 0,16 & 12,075 & 9,65 & $*$ & $*$ \\
\hline 5.İstasyon & 0,13 & 12,175 & 10,35 & $*$ & $*$ \\
\hline 6.İstasyon & 0,13 & 10,8 & 9,6 & $*$ & $*$ \\
\hline
\end{tabular}

MK: Maksimum konsantrasyon

SK: Sürekli konsantrasyon

*: Cihazın ölçüm duyarlılığının altında kaldığından tespit edilememiştir.

Bu çalışmada, Aksu Çayı ve Sır Baraj Gölü'nde belirlenen istasyonlardan alınan su örneklerindeki ağır metal değerleri, WHO ve EC tarafindan verilen standart değerlere göre de karşılaştırılmıştır (Tablo 8). Buna göre $\mathrm{Fe}, \mathrm{Cu}, \mathrm{Zn}, \mathrm{Cr}$ ve Ni konsantrasyonları WHO [28] ve EC [29] tarafından belirlenen maksimum değerlerin çok üzerinde çıkmıştır. Bu veriler ışığında tekstil, kaplama ve diğer endüstri fabrikalarından Aksu Çayı'na deşarj olan atık suların Sır Baraj Gölü'ne ağır metal taşıdığını açıkça ortaya koymaktadır.

Tablo 8. WHO [28] ve EC [29] tarafindan ağır metaller için verilen standart değerler ve bu çalışmada su örneklerinde belirlenen ağır metal konsantrasyonları (mg/L)

\begin{tabular}{|l|c|l|c|c|}
\hline Metaller & $\mathbf{Z n}$ & $\mathbf{F e}$ & $\mathbf{N i}$ & $\mathbf{C u}$ \\
\hline WHO [28] & - & 0,3 & - & - \\
\hline EC [29] & - & 0,2 & 0,02 & 2 \\
\hline 1. ̇̇stasyon & 48,87 & 64,47 & 1,52 & 18,45 \\
\hline 2.İstasyon & 49,02 & 64,1 & 1,45 & 14,47 \\
\hline 3. İstasyon & 47,6 & 72,02 & 1,52 & 16,15 \\
\hline 4. İstasyon & 9,65 & 12,075 & $*$ & 0,16 \\
\hline 5.İstasyon & 10,35 & 12,175 & $*$ & 0,13 \\
\hline 6. İstasyon & 9,6 & 10,8 & $*$ & 0,13 \\
\hline
\end{tabular}

*: Cihazın ölçüm sınırının altında olduğundan belirlenememiştir.

\section{Sonuç ve Öneriler}

Sürdürülebilir kalkınma yaklaşımı doğrultusunda her alanda olduğu gibi çevre ile ilgili araştırmalarda da çözüme ulaşmak için öncelikle sorunları bilmek ve anlamak gerekir. Son yıllarda çevre sorunları küreselleşmenin bir sonucu olarak uluslararası bir boyut kazanmaya başlamış ve dünyanın ortak sorunu haline gelmiştir. Bu nedenle çevre sorunları insan sağlı̆̆ ve doğal dengeyi korumak adına ülkelerin gündem maddeleri içinde üst sıralarda yer almaya başlamıştır. Dolayısıyla bütün sucul ekosistemlerde de kirliliğe neden olan kirletici kaynakların belirlenmesi, bu kirletici kaynakların canlılar ve su kalitesi üzerindeki olumsuz etkilerinin araştırılması büyük önem kazanmıştır. Çevresel değerleri sürdürebilmek için çevre kirliliği ile ilgili sorunların ulusal ve uluslararası boyutunun ele alınarak önerilerde bulunulması ve uygulamaya konulması gerekmektedir. Bu çalışma sonucunda elde edilen veriler 1şığında tekstil, kaplama ve diğer endüstriyel tesisler ve fabrikalardan Aksu Çayı'na deşarj olan atık suların Sır Baraj Gölü’ne ağır metal taşıdığı sonucuna varılmış olup, çevresel felaketlerin önlenmesi için bütün işletmelerde arıtma tesislerinin kurulması ve etkin bir şekilde çalıştırılması büyük önem arz etmektedir. 


\section{Teşekkür}

Bu çalışmayı maddi yönden destekleyen (FÜBAP-SÜF 12.11) Fırat Üniversitesi Bilimsel Araştırma Projeleri Koordinasyon Birimi’ne teşekkür ederiz. Bu çalışma yüksek lisans tezinden türetilmiştir.

\section{Kaynaklar}

[1] Förstner U., Wittmann G.T.W. 1983. Metal Pollution in the Aquatic Environments. SpringerVerlag, Berlin, Germany, 366p.

[2] Perry J., Vanderklein E. 1996. Water Quality Management of a Natural Resource. Blackwell Science, 639p,

[3] Al-Yousuf M.H., El-Shahawi Al-Ghais S.M. 2000. Trace Metals in Liver, Skin, and Muscle of Lethrinas lentjan Fish Species in Relation to Body Length and Sex. Science of the Total Environment, 256: 87-94.

[4] Alam M.G.M,, Tanaka A., Allinson G., Laurensen L.J.B., Stagnitti F., Snow E.T. 2002. A Comparison of Trace Element Concentrations in Cultured and Wild Carp (Cyprinus carpio) of Lake Kasumigaura, Japan. Ecotoxicology and Environmental Safety, 53: 348-354.

[5] Liaghati T., Proda M., Malcolm C. 2003. Heavy Metal Distribution and Controlling Factors within Costal Plain Sediments, Bell Grek Catchment, Southeast Queensland, Australia. Environment International, 29: 935-948.

[6] Ikem A., Egiebor N.O. 2005. Assessment of Trace Element in Canned Fish (Mackerel, Tuna, Salmon, Sardines and Herrings) Marketed in Georgia and Alabama (United States of America). Journal of Food Composition and Analyses, 18: 771-787.

[7] Brodheridge R.M., Newton K.E., Taggart M.A., Mccormick P.H., Evans S.W. 1998. Nickel, Cobalt, Zinc and Copper Levels in Brown Trout (Salmo trutta) from the River Otra, Soutern Norway. Analyst, 123: 69-72.

[8] Phipps D.A. 1981. Chemistry and Biochemistry of Trace Metals in Biological Systems, in Effect of Heavy Metal Pollution on Plant. Edited by Lepp N.W. London, UK, Applied Science Publishers, 1-54.

[9] Carranza-Alvarez C., Alonso-Castro A.J., Alfaro-De La Torre M.C., Garcia-De La Cruz R.F. 2008. Accumulation and Distribution of Heavy Metals in Scirpus americanus and Typha latifolia from an Artificial Lagoon in San Luis Potos, Mexico, Water Air Soil Pollution, 188: 297-309.

[10] Babula P., Adam V., Opatrilova R., Zehnalek J., Havel L., Kizek R. 2008. Uncommon Heavy Metals, Metalloids and their Plant Toxicity a Review. Environmental Chemistry Letters, 6,189213.

[11] Yılmaz F. 2004. Mumcular Barajı (Muğla-Bodrum)'nın fiziko-kimyasal özellikleri. Ekoloji, 13 (50): 10-17.

[12] Gürbüz M. 2001. Kahramanmaraş Merkez İlçe'nin Beşeri ve İktisadi Coğrafyası. İl Kültür Müdürlüğü Yayınları, Kahramanmaraş, No: 2, 241s,

[13] Toroğlu E., Toroğlu S., Alaeddinoğlu F. 2006. Aksu Çayı'nda (Kahramanmaraş) akarsu kirliliği. Coğrafi Bilimler Dergisi, 4: 93-103.

[14] Kumru S. 2009. Sır Barajı Gölü’nde (Kahramanmaraş) Zooplankton Yoğunluğunun Aylara ve Derinliğe Göre Değişimi. Yüksek Lisans Tezi, Kahramanmaraş Sütçü İmam Üniversitesi, Fen Bilimleri Enstitüsü, Kahramanmaraş.

[15] Kara C. 1999. Sir Baraj Gölü'nde Yaşayan Chondrostoma regium (Heckel, 1843) ve Leuciscus cephalus (Linn. 1758)'un Bazı Biyolojik Özellikleri. Doktora Tezi, Gazi Üniversitesi, Fen Bilimleri Enstitüsü, 105s, Ankara,

[16] Çömlekçioglu U. 2003. Sir Baraj Gölü Kirliliğinin Fizikokimyasal Parametrelerle İncelenmesi. Yüksek Lisans Tezi, Kahramanmaraş Sütçü İmam Üniversitesi, Fen Bilimleri Enstitüsü, 80s, Kahramanmaraș.

[17] URL. http:// www.googleearth.com, (Erişim tarihi: 18.02.2019).

[18] Cataldo D., Colombo J.C., Boltovskoy D., Bilos C., Landons P. 2001. Environmental Toxicity Assessment in the Parana River Delta (Argentina): Simultaneous Evaluation of Selected Pollutants and Mortality Rates of Corbicula fluminea (Bivalvia) Early Juveniles. Environment 
Pollution, 112: 379-389.

[19] APHA 1985. Standart Methods for Examination of Water and Wastewater. 16th ed. American Public Health Assosiciation, Washington, 1268 p.

[20] Teber Ç. 2013. Sıdıklı Küçükboğaz Baraj Gölü (Kırşehir)'nde Yaşayan Kadife Balığı (Tinca tinca L.,1758)'nda Ağır Metal Birikimi. Yüksek Lisans Tezi, Ahi Evran Üniversitesi, Fen Bilimleri Enstitüsü, 76s, Kırșehir.

[21] Sönmez A., Hisar O., Yanık T. 2012. Karasu Irmağı’nda Ağır Metal Kirliliğinin Tespiti ve Su Kalitesine Göre Sınıflandırılması. Atatürk Üniversitesi Ziraat Fakültesi Dergisi, 43 (1): 69-77.

[22] Kalyoncu H., Özan C., Tekin-Özan S. 2016. Isparta Deresi'nin Su ve Sedimentlerindeki Ağır Metal Birikiminin İncelenmesi. Mehmet Akif Ersoy Üniversitesi Fen Bilimleri Enstitüsü Dergisi, 7 (Ek Sayı 1): 268-280.

[23] Dündar M.Ş., Altundağ H., Kaygaldurak S., Şar V., Acar A. 2012. Çeşitli Endüstriyel Atık Sularda Ağır Metal Düzeylerinin Belirlenmesi. Sakarya Üniversitesi Fen Bilimleri Dergisi, 16 (1): 6-12.

[24] Uçkun A.A., Yoloğlu E., Uçkun M. 2017. Seasonal Monitoring of Metals in Water, Sediment and Mussel (Unio mancus) from Atatürk Dam Lake (Euphrates River). Van Veterinary Journal, 28 (2): 75-83.

[25] Minareci O., Çakır M. 2018. Determination of Detergent, Phosphate, Boron and Heavy Metal Pollution in Adıgüzel Dam Lake (Denizli/Turkey). Iğdır University Journal of the Institute Science and Technology, 8 (1): 61-67.

[26] Varol M. 2019. Arsenic and Trace Metals in a Large Reservoir: Seasonal and Spatial Variations, Source Identification and Risk Assessment for both Residential and Recreational Users. Chemosphere, 228: 1-8.

[27] USEPA 2002. National Recommended Water Quality Criteria. Office of Water, 822-R-02-047.

[28] WHO 1993. Guidelines for Drinking Water Quality, Recommendations. Edited by World Health Organization, Geneva, 2nd., Vol. 1.

[29] Environment Canada, 1994. Monitoring Surface Water Quality: A Guide for Citizens. Students and Communities in Atlantic Canada, $101 \mathrm{p}$. 